\title{
HEALTH RISK BEHAVIOR OF ADOLESCENT SCHOLARS ${ }^{1}$
}

\author{
Franck Nei Monteiro Barbosa², Cezar Augusto Casotti², Adriana Alves Nery4
}

${ }^{1}$ Article extracted from thesis - Comportamento de risco à saúde em adolescentes, presented to the Programa de Pós-Graduação em Enfermagem e Saúde, Universidade Estadual do Sudoeste da Bahia (UESB), in 2014.

${ }^{2}$ M.Sc. in Nursing and Health. Assistant Professor in Departamento de Saúde 1, UESB.Jequié, Bahia, Brasil. E-mail: francknei@yahoo. com.br

${ }^{3}$ Ph.D. in Preventative and Social Odontology. Professor in the Departamento de Saúde 1, UESB. Jequié, Bahia. Brasil. E-mail: cacasotti@uesb.edu.br

${ }^{4}$ Ph.D. in Nursing and Public Health. Professor in the Departamento de Saúde 2, UESB. Jequié, Bahia, Brasil. E-mail: aanery@ gmail.com

\begin{abstract}
The aim of this study was to describe health risk behaviors among adolescents from secondary education in public schools in a city in Brazilian Northeast. Epidemiological cross-sectional, population-based study with a simple random sample. For the data, we used structured validated questionnaires. For data analysis, we used the chi-square Pearson test, with significance level of $5 \%$. It has been found that physical inactivity is associated with the sex, age and studying shift. Tobacco consumption is significantly associated with sex, age, shift studying and alcohol consumption shift to studying, and age. As for poor dietary habits, consumption of fried foods is associated with shift in studying and sweets and sodas to shift on studying and age. Found a high prevalence of risk behaviors among adolescents, focused on policies needed health of this population.
\end{abstract}

DESCRIPTORS: Adolescent behavior. Sedentary lifestyle. Ethanol. Tobacco. Food habits.

\section{COMPORTAMENTO DE RISCO À SAÚDE DE ADOLESCENTES ESCOLARES}

RESUMO: O objetivo deste estudo foi descrever os comportamentos de risco à saúde de adolescentes escolares do ensino médio das escolas públicas de um município do Nordeste brasileiro. Estudo epidemiológico, transversal, de base populacional, com amostra aleatória simples. Para obter os dados, utilizaram-se questionários estruturados e validados. Para análise dos dados, utilizou-se o teste qui-quadrado de Pearson, com nível de significância 5\%. Verificou-se que a inatividade física está associada ao sexo, turno que estuda e idade. O consumo de tabaco está associado significativamente ao sexo, turno que estuda e idade e o consumo de álcool ao turno que estuda e idade. Quanto aos hábitos alimentares inadequados, o consumo de frituras está associado ao turno em que estuda e o de doces e refrigerantes ao turno em que estuda e idade. Constatou-se alta prevalência de comportamentos de riscos entre os adolescentes, sendo necessárias políticas voltadas para a saúde dessa população.

DESCRITORES: Comportamento do adolescente. Estilo de vida sedentário. Etanol. Tabaco. Hábitos alimentares.

\section{COMPORTAMIENTO DE RIESGO A LA SALUD DE ADOLESCENTES ESCOLARES}

RESUMEN: El objetivo de este estudio fue describir los comportamientos de riesgo a la salud entre adolescentes de educación secundaria en las escuelas públicas en una ciudad del nordeste de Brasil. Estudio epidemiológico, transversal, de base poblacional con una muestra aleatoria simple. Para obtener los datos, hemos utilizado cuestionarios estructurados y validados. Para el análisis de los datos, se utilizó el test de Chi cuadrado, con un nivel de significación del $5 \%$. Se ha encontrado que la inactividad física está asociada con el sexo, la edad y el periodo de estudio. El consumo de tabaco se asocia significativamente con el sexo, la edad y el periodo de estudio y consumo de alcohol al periodo de estudio y edad. En cuanto a los malos hábitos alimenticios, el consumo de alimentos fritos se asocia con el período de estudio y los dulces y las bebidas gaseosas con el período de estudio y la edad. Encontramos una alta prevalencia de conductas de riesgo entre los adolescentes, además es necesario implementar políticas para mejorarse la salud de la población.

DESCRIPTORES: Comportamiento del adolescente. Estilo de vida sedentario. Etanol. Tabaco. Hábitos alimenticios. 


\section{INTRODUCTION}

Adolescence is a time of life marked by numerous biological, cognitive and social changes taking place simultaneously and contribute to building personality, being an important process of human development, chronologically understood as between 10 to 19 anos. $^{1-2}$

Because it is a full transformation process, with repercussions of varying scopes for life in society, adolescence is a period of physical vulnerability, psychologically and socially, whose complexity profits from the special attention from parents, teachers, professionals health and competent organizations. $^{3}$

Given the specificity of being a teenager, adolescence is a critical period where various habits and behaviors are established. This lifestyle, understood as behaviors adopted day-to-day, can cause health problems and disorders in adolescence or adulthood, but also trigger chronic non communicable diseases. ${ }^{4-5}$

Risky behavior adopted by adolescents can be understood as activities that may endanger health, such as alcohol consumption, smoking, poor eating habits, physical inactivity, unprotected sex, among others. This form of understanding, acts and positions itself towards the reality that is influenced by the family and social context, as a school, community, friends and the media. Thus, in view of the seriousness of these behaviors, it is important to identify and incorporate prevention and health promotion of adolescents early in order to avoid problems in adult life. ${ }^{6}$

Despite the recognition of the importance of adopting positive health behaviors, the prevalence of health risk behaviors is high among adolescents from different social contexts. A study of high school students in the United States found that $38.7 \%$ of adolescents consumed alcohol, $18.1 \%$ had smoked cigarettes, $4.8 \%$ did not eat fruit and $5.7 \%$ did not eat vegetables. ${ }^{7}$ In Portugal, 38 8\% had a low level of physical activity, $48.7 \%$ inadequate consumption of fruits and $62.7 \%$ of vegetables. ${ }^{8}$ In Brazil, $27.3 \%$ of students consumed alcohol, $6.3 \%$ were smokers and only $43,1 \%$ were considered physically. ${ }^{9}$

Due to the importance of identifying health risk behaviors in Brazilian students, to plan, propose and implement actions to promote the health of this population and, considering the lack of data from the Northeast of Brazil, mainly in mid-sized municipalities, this study aimed to describe health risk behaviors of adolescent high school students of public schools in a city in northeastern Brazil.

\section{METHOD}

This is a cross-sectional epidemiological study, population-based by simple random sampling, conducted with schoolchildren from the city of Jequié-BA, in the 2012 period.

The Jequié municipality is located in the South-Central region of the State of Bahia, it has an estimated population of 151,895 inhabitants ${ }^{10}$ and, according to information from the 13th Regional Center of Education in the Bahia State, there are 16 public schools belonging to the state that offer high school, 12 located in the urban area and four in the rural area.

A simple random sample was chosen with replacement of the sample element not identified in the school during the course of the invitation to participate in the study. In view of this, we obtained a list from the 13th Regional Center of Education with the name of the scholar, date of birth, class year, class group, name and the addresses of the state run public high schools in the municipality. Then we identified the scholars aged 14 to 19 years $(n=4,355)$ which, as a result, were numbered in ascending order (1-4,355).

After this took place the sample size calculation was performed using the Epi-info program (3.5.1), and with prevalence of physical inactivity of $65.7 \%,{ }^{4}$ confidence level of $95 \%$ and accuracy of $3 \%$, was adopted, totaling 788 schools, to which $10 \%$ was added, foreseeing the possible losses and refusals, which increased the sample to 867 scholars.

Next, we calculated the sample interval $(n=5)$ and the first element in the range was randomly picked (3), then this increased the value of the sampling interval (5), in order to identify other students who participated in the study.

On obtaining the name of the randomly picked scholar, knowing the school, the class group and the year where the student studied, the researchers directed themselves to the teaching units to invite the students to participate in the study. Those who accepted the invitation, were given a copy of the Informed Consent form (IC) for those responsible for the participants under 18 in order to authorize their participation. On this occasion, the students randomly selected for the sample that were not in the classroom or refused to participate in the study were replaced in the list by the first name above theirs. 
Data collection was performed on the day and time previously scheduled with the direction of the schools, between the months of July to September 2012, using an available room for this purpose. The randomly selected students who delivered the signed consent form were invited to go to the room provided by the school, where they would respond to the questionnaire.

The following were criteria for inclusion of subjects in the study: to be aged between 14-19 years; study in public school which offered high school in urban and rural areas of the municipality of Jequié; to be regularly enrolled; study in one of the morning, afternoon or night shifts; be present in the classroom at the time of delivery of IC and data collection; agree to participate.

To collect the information, a validated questionnaire was used for the sociodemographic survey, physical activity, eating habits (consumption of fried foods, sweets, soft drinks, fruits and vegetables), tobacco use and alcohol consumption. This instrument was adapted and used in a population survey. ${ }^{11}$ Data on economic classification were obtained through the Brazilian Research Companies Association (ABEP) questionnaire. ${ }^{12}$

Prior to the data collection taking place theoretical and practical workshops were performed to standardize the use and application of the data collection instrument. A pilot study was conducted in a high school in a small town in the same region to assess the accuracy of the instrument in achieving the objectives of this study. At this stage it identified the time required for the school to respond to the questionnaire, and that it would not be necessary to make adjustments to the data collection instrument.

The following were classified as dependent variables: the level of physical activity (reporting daily activity two days a week and one day on the weekend), those students whose energy consumption was less than or equal to $36,9 \mathrm{Kcal} / \mathrm{kg}$ per day were considered physically inactive, ${ }^{13}$ tobacco use (does not smoke and smoked cigarettes in the last 30 days); alcohol (does not drink and drank in the last 30 days) and eating habits (weekly frequency of consumption of fried foods, sweets and soft drinks, fruits and natural juices and vegetables), the consumption of fried foods, fatty foods, sweets and soft drinks when consumption was greater than or equal to three days a week, considered as poor habits, and inadequate consumption of fruits and vegetables where the consumption of these were less than five days in a week. ${ }^{14}$

The independent variables were: age (years), sex (male and female); education of adolescents (1st, 2nd and 3rd year of high school); shift in studying, day (morning and afternoon - this junction occurred because significant statistical differences between these was not identified in the analysis) and night; work (yes, no); the father and the mother (completed elementary education, secondary education, higher education and does not know to inform); who they live with (father/mother, grandparents, uncles, etc.); religion (no religion, catholic, evangelical, spiritualist, others); family composition (number of siblings living in the household); ethnicity (white, brown, negro, black, Indian) and economy class (A to E). Only the independent variables were dichotomized for statistical analysis.

Data were entered twice in the Epi Data program and then matched. The identified were corrected and then analyzed using SPSS (21.0). A descriptive analysis of the variables was performed, with mean, standard deviation, as well as absolute and relative frequencies, the bivariate analysis was performed through the test of association between independent variables and the outcomes studied, using the chi-square Pearson test, taking as significance level $\mathrm{p}<0.05$.

This study was approved by the Research Ethics Committee of the Universidade Estadual do Sudoeste da Bahia (CAAE: 00183.0.454.000-11).

\section{RESULTS}

The sample consisted of 840 high school students enrolled in public schools.

Table 1 - Socio-demographic characteristics of high school students of the municipality, according to sex. Jequié- BA, 2011

\begin{tabular}{|c|c|c|c|c|c|c|}
\hline \multirow[t]{2}{*}{ Variable } & \multicolumn{2}{|c|}{ Masculine } & \multicolumn{2}{|c|}{ Feminine } & \multicolumn{2}{|c|}{ All } \\
\hline & $\mathbf{n}$ & $\%$ & $\mathbf{n}$ & $\%$ & $\mathbf{n}$ & $\%$ \\
\hline Sex & 331 & 40,0 & 496 & 60,0 & 827 & 100 \\
\hline \multicolumn{7}{|c|}{ Age group (805) } \\
\hline 14 a 16 & 154 & 19,1 & 240 & 29,8 & 394 & 48,9 \\
\hline 17 a 19 & 169 & 21,0 & 242 & 30,1 & 411 & 51,1 \\
\hline
\end{tabular}




\begin{tabular}{|c|c|c|c|c|c|c|}
\hline \multirow[t]{2}{*}{ Variable } & \multicolumn{2}{|c|}{ Masculine } & \multicolumn{2}{|c|}{ Feminine } & \multicolumn{2}{|c|}{ All } \\
\hline & $\mathbf{n}$ & $\%$ & $\mathbf{n}$ & $\%$ & $\mathbf{n}$ & $\%$ \\
\hline Father/Mother & 268 & 32,6 & 375 & 45,7 & 643 & 78,3 \\
\hline Other & 60 & 7,3 & 118 & 14,4 & 178 & 21,7 \\
\hline \multicolumn{7}{|l|}{ Study period (827) } \\
\hline Day time & 270 & 32,6 & 433 & 52,4 & 703 & 85,0 \\
\hline Night time & 61 & 7,4 & 63 & 7,6 & 124 & 15,0 \\
\hline \multicolumn{7}{|l|}{ Grade (827) } \\
\hline 1 st & 147 & 17,8 & 183 & 22,1 & 330 & 39,9 \\
\hline 2nd & 98 & 11,9 & 181 & 21,9 & 279 & 33,7 \\
\hline $3 r d$ & 86 & 10,4 & 132 & 16,0 & 218 & 26,4 \\
\hline \multicolumn{7}{|l|}{$\mathrm{N}^{\mathrm{o}}$ of siblings $(801)$} \\
\hline Zero & 53 & 6,6 & 93 & 11,6 & 146 & 18,2 \\
\hline 1 or more & 270 & 33,7 & 385 & 48,1 & 655 & 81,8 \\
\hline \multicolumn{7}{|l|}{ Religion (823) } \\
\hline None & 73 & 8,9 & 56 & 6,8 & 129 & 15,7 \\
\hline Catholic & 105 & 12,8 & 198 & 24,1 & 303 & 36,8 \\
\hline Other & 151 & 18,3 & 240 & 29,2 & 391 & 47,5 \\
\hline \multicolumn{7}{|l|}{ Color of skin (809) } \\
\hline White & 57 & 7,0 & 101 & 12,5 & 158 & 19,5 \\
\hline Not white & 266 & 32,9 & 385 & 47,6 & 651 & 80,5 \\
\hline \multicolumn{7}{|l|}{ Working (808) } \\
\hline Yes & 119 & 14,7 & 127 & 15,7 & 246 & 30,4 \\
\hline No & 201 & 24,9 & 361 & 44,7 & 562 & 69,6 \\
\hline \multicolumn{7}{|c|}{ Level of education of father (803) } \\
\hline Until Primary & 155 & 19,3 & 295 & 36,7 & 450 & 56,0 \\
\hline High School & 87 & 10,8 & 111 & 13,8 & 198 & 24,7 \\
\hline College/ University & 74 & 9,2 & 64 & 8,0 & 138 & 17,2 \\
\hline Unknown & 05 & 0,6 & 12 & 1,5 & 17 & 2,1 \\
\hline \multicolumn{7}{|c|}{ Level of education of mother (822) } \\
\hline Until Primary & 137 & 16,7 & 271 & 33,0 & 408 & 49,6 \\
\hline High school & 102 & 12,4 & 137 & 16,7 & 239 & 29,1 \\
\hline College / University & 86 & 10,5 & 80 & 9,7 & 166 & 20,2 \\
\hline Unknown & 3 & 0,4 & 06 & 0,7 & 09 & 1,1 \\
\hline \multicolumn{7}{|l|}{ Socio economic level (825) } \\
\hline Most favorable (A, B) & 111 & 13,5 & 95 & 11,5 & 206 & 25,0 \\
\hline Less favorable $(C, D, E)$ & 219 & 26,5 & 400 & 48,5 & 619 & 75,0 \\
\hline \multicolumn{7}{|c|}{ Physical Activity Level (793) } \\
\hline Active & 194 & 24,5 & 158 & 19,9 & 352 & 44,4 \\
\hline Inactive & 122 & 15,4 & 319 & 40,2 & 441 & 55,6 \\
\hline
\end{tabular}

As noted in Table 1 of the evaluated adolescent students, $60 \%(n=496)$ were female, $51.1 \%(n=411)$ aged 17 to 19 years, $78.3 \%(n=643)$ live with father/ mother, $85.0 \%(n=703)$ study during the day shift, $39.9 \%(n=330)$ study in the 1st year of high school,
$81.8 \%(n=655)$ have one or more siblings, $805 \%$ $(n=651)$ say they are not white, $69.6 \%(n=562)$ do not work, $75.0 \%(n=619)$ are in the less favored socioeconomic level (C, D and E) and $55.6 \%(n=441)$ were classified as physically inactive.

Table 2 - Prevalence of health risk behavior of high school students of the municipality, according to gender. Jequié- BA, 2011

\begin{tabular}{|c|c|c|c|c|c|}
\hline \multirow[t]{2}{*}{ Variable } & \multicolumn{2}{|c|}{ Masculine } & \multicolumn{2}{|c|}{ Feminine } & \multirow[t]{2}{*}{$p$} \\
\hline & $\mathrm{n}$ & $\%$ & $\mathrm{n}$ & $\%$ & \\
\hline $\begin{array}{l}\text { Insufficient level of physical activity } \\
\text { Dietary habits }\end{array}$ & 122 & 38,6 & 319 & 66,9 & $<0,0001$ \\
\hline
\end{tabular}


Inappropriate consumption of fried foods

Inappropriate consumption of sweets/ soda

Inadequate consumption of fruit

Inadequate consumption of vegetables

Alcohol consumption

Tabaco use

\begin{tabular}{ccccc}
121 & 37,1 & 175 & 35,6 & 0,710 \\
183 & 55,8 & 297 & 60,6 & 0,192 \\
86 & 26,2 & 135 & 27,5 & 0,748 \\
114 & 35,0 & 158 & 32,4 & 0,495 \\
129 & 40,1 & 185 & 38,0 & 0,556 \\
25 & 7,7 & 11 & 2,3 & $<0,0001$ \\
\hline
\end{tabular}

Among the seven behaviors evaluated in Table 2 , the boys had a higher prevalence of health risk behaviors due to inappropriate intake of fried food (37.1\%), low consumption of vegetables $(35.0 \%)$, alcohol consumption $(40,1 \%)$ and tobacco $(7.7 \%)$, and the girls with insufficient levels of physical ac- tivity $(66.9 \%)$, excessive consumption of sweets and soft drinks (60.6\%) and low consumption of fruits $(27.5 \%)$. There was a significant difference between genders for the variables insufficient levels of physical activity $(\mathrm{p}<0.0001)$ and tobacco consumption $(p<0.0001)$.

Table 3 - Prevalence of health risk behavior of high school students in the municipality, according to study shift. Jequié- BA, 2011

\begin{tabular}{lccccc}
\hline Variable & \multicolumn{2}{c}{ Day time } & \multicolumn{2}{c}{ Night time } & \multirow{2}{*}{$p$} \\
\cline { 2 - 4 } & $\mathbf{n}$ & $\mathbf{0}$ & $\mathbf{n}$ & $\mathbf{\%}$ & \\
\hline Insufficient level of physical activity & 402 & 59,1 & 46 & 36,8 & $<\mathbf{0 , 0 0 0 1}$ \\
Dietary habits & & & & & \\
Inappropriate consumption of fried foods & 265 & 37,6 & 35 & 27,8 & $\mathbf{0 , 0 3 5}$ \\
Inappropriate consumption of sweets/ soda & 433 & 61,4 & 57 & 45,2 & $\mathbf{0 , 0 0 1}$ \\
Inadequate consumption of fruit & 186 & 26,4 & 36 & 28,3 & 0,663 \\
Inadequate consumption of vegetables & 238 & 34,0 & 41 & 32,8 & 0,838 \\
Alcohol consumption & 258 & 37,1 & 61 & 49,2 & $\mathbf{0 , 0 1 2}$ \\
Tabaco use & 26 & 3,7 & 10 & 9,1 & $\mathbf{0 , 0 2 0}$ \\
\hline
\end{tabular}

As noted in Table 3, the children enrolled in the day shift had a higher prevalence of insufficient physical activity (59.1\%), excessive consumption of fried food $(37.6 \%)$, excessive consumption of sweets and soft drinks $(61.4 \%)$ and low consumption of vegetables $(34.0 \%)$, while adolescents studying in the night shift prevailed with low consumption of fruits $(28.3 \%)$, alcoholic drinks (49.2\%) and tobacco (9.1\%).
When comparing the risk behavior prevalence according to the time/ shift in which they study, significant differences were identified between insufficient levels of physical activity ( $p<0.0001)$, excessive consumption of fried foods $(p=0.035)$, excessive consumption of sweets / soft drinks ( $\mathrm{p}=0.001)$, alcohol $(\mathrm{p}=0.012)$ and cigarette smoking $(\mathrm{p}=0.020)$.

Table 4 - Prevalence of health risk behavior of high school students of the municipality, according to age. Jequié- BA, 2011

\begin{tabular}{|c|c|c|c|c|c|}
\hline \multirow[t]{2}{*}{ Variable } & \multicolumn{2}{|c|}{$14-16$ years old } & \multicolumn{2}{|c|}{ 17- 19 years old } & \multirow[t]{2}{*}{$p$} \\
\hline & $\mathbf{n}$ & $\%$ & $\mathbf{n}$ & $\%$ & \\
\hline Insufficient level of physical activity & 243 & 63,0 & 195 & 49,2 & $<0,0001$ \\
\hline \multicolumn{6}{|l|}{ Dietary habits } \\
\hline Inappropriate consumption of fried foods & 157 & 39,4 & 137 & 33,5 & 0,080 \\
\hline Inappropriate consumption of sweets/ soda & 262 & 65,5 & 213 & 52,2 & $<0,0001$ \\
\hline Inadequate consumption of fruit & 105 & 26,4 & 110 & 26,8 & 0,937 \\
\hline Inadequate consumption of vegetables & 131 & 32,9 & 141 & 34,8 & 0,602 \\
\hline Alcohol consumption & 123 & 31,5 & 186 & 45,7 & $<0,0001$ \\
\hline Tabaco use & 09 & 2,3 & 25 & 6,2 & 0,008 \\
\hline
\end{tabular}


When health risk behaviors by age group were evaluated (Table 4), it is clear that older adolescents (17-19 years) have a higher prevalence of low consumption of fruits $(26.82 \%)$, low consumption of vegetables $(34.8 \%)$, higher alcohol consumption $(45.7 \%)$ and smoking (6.2\%). Among the youngest (14-16 years) the most prevalent behaviors were insufficient levels of physical activity $(63.0 \%)$, excessive consumption of fried food (39.4\%) and excessive consumption of sweets and soft drinks (65.5\%).

Significant differences were observed between age groups regarding the insufficient level of physical activity $(\mathrm{p}<0.0001)$, excessive consumption of sweets and soft drinks ( $\mathrm{p}<0.0001)$, alcohol consumption $(\mathrm{p}<0.0001)$ and smoking $(\mathrm{p}=0.008)$.

\section{DISCUSSION}

Health risk behaviors adopted by adolescents are associated with morbidity and mortality in this age group, and can trigger various problems such as sexually transmitted diseases, unwanted pregnancy, organ dysfunction and chronic non communicable diseases. ${ }^{11,14}$

Among the risk factors, physical activity is recognized as an important factor for the promotion of health and prevention of chronic diseases and is recommended for all age groups, and is the subject of studies and recommendations on a global level, with a view to obtaining the benefits generated by its regular practice, ${ }^{2}$ however, a political decision is necessary to implement, in a positive way, a physical activity program, seeking to achieve sufficient and recommended levels for this practice, and proper guidance to the target audience. ${ }^{2}$

With regard to this study, the adolescents had high prevalence of physical inactivity in the three discussed aspects (sex, study shift and age), corroborating the results found in students of other nationalities, as well as students of Brazilian capitals. ${ }^{2,8-9}$

The study also points out that girls are more physically inactive than boys, corroborating studies in the United States, ${ }^{7}$ in Europe ${ }^{8}$ and other studies in Brasil ${ }^{4,9,15-17}$ and Jequié-BA, in 2011, with sample not representative of students of the same age group from public educative networks. ${ }^{18}$ This finding is worrying and shows the need for intervention to reverse this reality and its serious consequences for the health of these people.

The adoption of inappropriate eating habits also deserves special attention. Healthy eating can promote many benefits, generate energy needed for daily life activities, helps with studying and in the prevention and treatment of diseases. Having a healthy diet is necessary to maintain a good lifestyle $^{19}$ and promote the health of scholar. ${ }^{20}$

Our study found a high prevalence of adolescents with poor eating habits. In both sexes there was overconsumption of sweets and soft drinks. Students enrolled in morning and afternoon shifts showed worse eating habits compared to students studying at night, especially in relation to inadequate consumption of vegetables. With regard to age, the two groups surveyed adopt poor eating habits and this becomes clearer in the excessive consumption of fried food.

In the sample analyzed in this study there was no statistically significant difference between poor eating habits and sex, corroborating the findings of other studies. ${ }^{14,21-22}$

When comparing the eating habits of students from Jequié-BA, according to the shift in which they studied (day and night), we verify that the students in the school day shift have a higher number of poor eating habits. Statistically significant differences were found only for inappropriate intake of fried foods, sweets and soft drinks. Results found in Florianópolis-SC have already identified the inadequate consumption of fruit for the students who study at night. ${ }^{14}$

Comparing the eating habits according to age, it is clear that the prevalence is high. Among the younger students, a significant statistical difference was identified for the inappropriate consumption of sweets and soft drinks. Discordant data were obtained in other studies conducted with schoolchildren from Florianópolis, SC, seeing that, according to the authors, eating habits do not suffer due to the influence of age. ${ }^{4,14}$ Which may have influence the higher consumption of sweets and soft drinks among the student youths from Jequié-BA, possibly, is related to public policies of income transfer, allowing greater access to this type of food in the recipient households. Note that in all state schools in the city, the sale of food was banned and the only thing being offered were the school meals.

Considering the consumption of alcohol, there was a significant difference between the prevalence in relation to the study shift and age, with the highest prevalence for students in the night shift and among the older students. Similar results were found in students Recife ${ }^{23}$ and North America. ${ }^{7}$ Alcohol consumption can cause harmful health 
effects and serious social problems, if no measures are taken to prevent and change the habit.

A study of Spanish adolescents identified a relationship between the consumption of alcohol and other psychoactive substances, which is a social problem of the first magnitude. Students who consume alcohol are more permissive, have emotional instability and disturbing behaviors. ${ }^{24-25}$ Generally, alcohol is associated with pleasure, sociability and joy, but we cannot forget the harm caused by alcohol, which can cause addiction, the occurrence of accidents and other social order problems. ${ }^{26-28}$

With regard to tobacco consumption, we identify statistically significant differences between the prevalence of consumption, according to gender, study shift and age. Tobacco use was higher among boys studying in the night shift and in the older group (17-19 years). As for tobacco consumption in relation to gender, discordant data was found in research with students from Rio de Janeiro-RJ, ${ }^{22,29}$ where the prevalence of smoking was higher among women, as a study conducted in Brazilian capitals, where there is no significant difference between the genders. ${ }^{30}$ Tobacco use can cause serious health problems, and in adolescents, is often associated with anxiety and depressive symptoms. ${ }^{31}$

There was an increase in the prevalence of tobacco consumption with increasing age, with the highest prevalence for students aged 17 to 19 years. Similar data were obtained in a study conducted in Brazilian capitals,,$^{30}$ which corroborates the results found in our study. In another study conducted in the city of Pelotas, it was found that the chance of an adolescent aged 17 to 18 years being a smoker is 4.35 higher compared to that of a 12 to 14 year old adolescent. $^{32}$

This study presents the fact of using a crosssectional study design and that the sample only consists of teenagers who attended public high schools as limitations. Therefore, adolescents studying at other levels of education, as well as those enrolled in private schools were excluded. To ensure the confidentiality of answers, it was decided to leave an urn at the back of the room where the completed forms were placed. Despite these careful measures and choosing a suitable place for the subjects to answer the questionnaire, it was not possible to guarantee that their answers had not been influenced, because they were in school, during school hours, so with tasks to do and surrounded by colleagues, this may have interfered in their reflections and answers.

\section{CONCLUSION}

Among adolescent students enrolled in public schools in the Jequié-BA municipality, high prevalences of health risk behaviors were identified.

In the sample analyzed there was a statistically significant difference between the prevalence of physical inactivity, being higher among female students, studying in the day shift, and the younger age group. There was also a statistically significant difference between the inappropriate intake of fried foods, which was higher in students in the day shift. Among the students, statistically significant differences regarding the consumption of alcohol and tobacco were identified. Alcohol use was more prevalent among students studying in the night shift and in the older age group and tobacco use was more prevalent among school adolescent males, the night shift and the older age group.

The high prevalence of health risk behaviors among adolescent students of Jequié-BA municipality shows that they are vulnerable, they can develop health problems and are likely to be adults with serious health problems.

It is necessary to implement public policies to meet the real needs of this population, as well as collective action by the family, school, society and government agencies seeking the prevention of risk behavior and increased attention to adolescent health.

\section{REFERENCES}

1. Davim RMB, Germano RM, Menezes RMV, Carlos, DJD. Adolescente/adolescência: revisão teórica sobre uma fase crítica da vida. Rev Rene. 2009; 10(2):131-40.

2. World Health Organization. Global recommendations on physical activity for health [Internet]. Geneva (CH): WHO; 2010 [cited 2012 Oct 20]. Available from: http://whqlibdoc.who.int/ publications/2010/9789241599979-eng.pdf

3. Heidemann M. Adolescência e saúde - uma visão preventiva para profissionais de saúde e educação. Petrópolis (RJ): Vozes, 2006.

4. Faria Junior JC, Lopes AS. Comportamentos de risco relacionados à saúde em adolescentes. Rev Bras Ci e Mov. 2004; 12(1):7-12.

5. Centre for Disease Control and Prevention. Youth risk behavior surveillance-United States, 2001 [Internet]. MMWR 2002 [cited 2013 Oct 20]; 51: 1-64. Available from: http://www.cdc.gov/mmwr/preview / mmwrhtml/ss5104a1.htm

6. Feijó RB, Oliveira EA. Comportamento de risco na adolescência. J Pediatr (Rio J) [Internet]. 2001 [cited 2013 Oct 20]. 77(Supl 2):S125-34. Available 
from: http:/ / www.lume.ufrgs.br/bitstream/ handle/10183/54698/000386001.pdf

7. Centers for Disease Control and Prevention. Youth Risk Behavior Surveillance - United States, 2011. MMWR. June 8, 2012 [cited 2015 Oct 20]; 61(4). Available from: http://www.cdc.gov/mmwr/pdf/ ss/ss6104.pdf

8. Matos MG, Simões C, Tomé G, Silva M, Gaspar T, Diniz JÁ. Aventura social \& saúde: indicadores de saúde dos adolescentes portugueses: relatório preliminar HBSC 2006 [cited 2012 Oct 20]. Available from: http://www.fmh.utl.pt/aventurasocial/pdf/ Indicadores_de_Saude.pdf

9. Instituto Brasileiro de Geografa e Estatística (BR). Pesquisa Nacional de Saúde do Escolar 2009. Rio de Janeiro (RJ): IBGE; 2009 [cited 2015 Oct 20]. Available from: http://www.ibge.gov.br/home/estatistica/ populacao/pense/pense.pdf

10. Instituto Brasileiro de Geografia e Estatística (BR). Cidades. [cited 2012 Oct 20]. Available from: http://www.cidades.ibge.gov.br/xtras/perfil. php?lang $=\&$ codmun $=2918001$

11. Farias Junior JC. Estilo de vida de adolescentes do município de Florianópolis, Santa Catarina, Brasil. Florianópolis [dissertação]. Florianópolis (SC): Universidade Federal de Santa Catarina, Centro de Desportos; 2002.

12. Associação Brasileira de Empresas de Pesquisa (BR). Critério de classificação econômica Brasil. 2012 [cited 2015 Oct 20]. Available from: http:// www.abep.org/ criterio-brasil

13. Cale L, Almond L. The physical activity levels of English adolescent boys. Eur J Phys Educ. 1997; 2: 74-82.

14. Loch MR, Nahas MV. Comportamentos negativos relacionados à saúde em estudantes do ensino médio de Florianópolis, SC. Rev Bras Atividade Física Saúde. 2006. 11(2):13-24.

15. Hallal PC. Epidemiologia da atividade física na adolescência. In: Anais do $5^{\circ}$ Congresso Brasileiro de Atividade Física e Saúde. Florianópolis, Santa Catarina, Brasil. Florianópolis; 17 a 19 novembro 2005:18-9

16. Farias Junior JC, Mendes JKF, Barbosa DBM. Associação entre comportamentos de risco à saúde em adolescentes. Rev Bras Cineantropom Desempenho Hum. 2007; 9(3):250-6.

17. Tassitano RM, Dumith SC, Chica DAG, Tenório MCM. Agregamento dos quatro principais comportamentos de risco às doenças não transmissíveis entre adolescentes. Rev Bras Epidemiol. 2014; 17(2):465-48.

18. Oliveira AO, Costa Neto SG, Silva Neto VR. Rocha $\mathrm{SV}$. Fatores associados à inatividade física entre adolescentes de uma escola pública do município de Jequié-BA. Ulbra e Movimento (REFUM). 2011; 2(1):30-44.
19. Agostinho LCL, Nascimento L, Cavalcanti BF. A química dos alimentos no processo de ensinoaprendizagem na Educação de Jovens e Adultos-EJA. Revista Lugares de Educação. 2012; 2(1):31-46.

20. Grillo LP, Klitzke CA, Campos IC, Mezadri T. Riscos nutricionais de escolares pertencentes a famílias de baixa renda no litoral Catarinense. Texto Contexto Enferm. 2005; 14(Esp.):17-23.

21. Farias Junior JC, Mendes JKF. Barbosa DBM, Lopes AS. Fatores de risco cardiovascular em adolescentes: prevalência e associação com fatores sociodemográficos. Rev Bras Epidemiol. 2011; 14(1):50-62.

22. Castro IRR, Cardoso LO, Engstrom EM, Levy RB, Monteiro CA. Vigilância de fatores de risco para doenças não transmissíveis entre adolescentes: a experiência da cidade do Rio de Janeiro, Brasil. Cad Saúde Publica. 2008; 24(10):2279-88.

23. Gomes BMR, Alves JGB, Nascimento LC. Consumo de álcool entre estudantes de escolas públicas da região metropolitana de Recife, Pernambuco, Brasil. Cad Saúde Pública. 2010; 26(4):706-12.

24. Moral VM, Rodriguez FJ, Pastor A. Correlatos psicosociales del consumo de sustancias psicoactivas en adolescentes españoles. Saúde Pública Mex. 2010; 52(5):406-15.

25. Mancha BE, Rojas VC, Latimer WW. Alcohol use, alcohol problems, and problem behavior engagement among students at two schools in northern Mexico. Alcohol. 2012 Nov;46(7):695-701.

26. Silva SED, Padilha MI. Alcoholism in adolescents' life histories: an analysis in the light of social representations. Texto Contexto Enferm [Internet]. 2013 [cited 2015 Oct 20]; 22(3):576-84. Available from: http://www.scielo.br/scielo.php?script=sci arttext\&pid=S0104-07072013000300002\&lng=en\&nr $\mathrm{m}=\mathrm{iso \& tlng}=\mathrm{en}$

27. Carvalho PD, Barros MVG, Lima RA, Santos CM, Mélo EN. Condutas de risco à saúde e indicadores de estresse psicossocial em adolescentes estudantes do Ensino Médio. Cad Saúde Pública. 2011; 27(11):2095105.

28. Birhanu AM, Bisetegn TA, Woldeyohannes SM. High prevalence of substance use and associated factors among high school adolescents in Woreta Town, Northwest Ethiopia: multi-domain factor analysis. BMC Public Health. 2014 Nov 20;14:1186.

29. Jorge KO, Cota LO, Ferreira EF, Vale MP, Kawachi I, Zarzar PM. Tobacco use and friendship networks: a cross-sectional study among Brazilian adolescents. Ciênc Saúde Coletiva. 2015. 20(5):1415-24.

30. Barreto SM, Giatti L, Casado L, Moura L, Crespo C, Malta DC. Exposição ao tabagismo entre escolares no Brasil. Ciênc Saúde Coletiva. 2010. 15(Supl.2):3027-34.

31. Cheron-Launay M, Baha M, Mautrait C, Lagrue G, Le Faou AL. Repérer lês comportements addictifs chez 
les adolescents: enquête em milieu Lycéen. Archives de Pédiatrie. 2011; 18:737-44.

32. Horta BL, Calheiro P, Pinheiro RT, Tomasi E, Amaral
KC. Tabagismo em adolescentes de área urbana na Região Sul do Brasil. Rev Saúde Pública. 2001. 352: 15-164. 